\title{
INCREASING STUDENT ACTIVITY IN HISTORY CLASSES AND THE USE OF LOCAL SECOND WORLD WAR HISTORY ISSUES
}

\author{
Nazokat Mamasoatovna Bozorova
}

Teacher, Retraining Of Public Educators Of Surkhandarya Region Training And Professional Development, Uzbekistan

\section{ABSTRACT}

In the learning process, the main task is to teach history, rely on a national basis, study the traditions of our people, such as enlightenment, tolerance, hospitality, caring, faith, kindness, honor and instill them in our hearts. young people. As in the case of the education system, the growing demand for lessons in modern history, the variety of subjects, the growing attention to historical sources, the daily need for modern pedagogical and information and communication technologies - this is the real picture of today's education.

KEYWORDS:- General education schools, student activity, education system, educational process, quality of education, creativity, information and communication technologies.

\section{INTRODUCTION}

The so-called historical blessing of independence has become an important factor in reviving the historical traditions and spiritual wealth of our people, enriching it with new content. In turn, the education system occupies a special place in this factor. In the learning process, the main task is to teach history, rely on a national basis, study the traditions of our people, such as enlightenment, tolerance, hospitality, thoughtfulness, honesty, kindness, honor and instill them in our hearts. young people.

Today, an honest, objective and in-depth study of the history of Surkhandarya and an understanding of its essence will help students understand the origins of the historical traditions of their ancestors, their historical composition.
As in the case of the education system, the growing demand for lessons in modern history, the variety of subjects, the growing attention to historical sources, the daily need for modern pedagogical and information and communication technologies - this is the real picture of today's education. In this regard, the words of President Shavkat Mirziyoyev are relevant: "If the teaching methodology at school does not change, the quality, content and learning environment will not change" [1]. Therefore, the creation of a true scientific history of our state, our people has become a very important and urgent problem for our general public. To find an effective solution to this important and topical issue, the agenda should include such a task as the formation of the historical consciousness of the younger generation. For this, in our opinion, it is necessary to create a creative environment in the 
CURRENT RESEARCH JOURNAL OF PEDAGOGICS 2(6): 157-160, June

2021 DOI: https://doi.org/10.37547/pedagogics-crjp-02-06-29

ISSN 2767-3278

(C)2021 Master Journals

\section{Crossref do) 81 Google}

Accepted 25th June, 2021 \& Published 30 $0^{\text {th }}$ June, 2021

educational process, which is primarily associated with a history lesson. In order for the reader to have a deep understanding of historical events, historical scenes, it is necessary to look for ways to awaken the spirit of creativity in him. Otherwise, methods such as teaching abstract imagination or the method of memorization are completely inadequate to the requirements of the time. Another important factor is to organize the activities of students in a certain order, that is, to find the maximum continuity of the topics covered in previous lessons with the content of subsequent lessons. What does it mean to awaken the spirit of creativity? Among the creative assignments used in the history lesson, writing creative works on specific topics of history plays an important role.

\section{Methods}

Through creative writing, students develop creative and historical thinking while simultaneously developing written language by presenting and expressing historical dates, events, personalities, and historical places in writing. The topics chosen for creative writing should also be based on specific requirements. In particular, the following topics are recommended as an example:

1. What do you know about the heroes who returned from the Great Patriotic War wounded? (Tell us about their post-war activities). Of course, when covering such a topic, the student should visit the homes of war veterans living in his area, neighborhoods, museums and talk about their heroism in the war. As a result, he simultaneously uses actions to restore, memorize and combine knowledge gained from other stories. In this context, the variety of topics for creative writing in history lessons increases student interest. For example, what profession or occupation the soldiers who returned wounded during the war have in their future career is certainly of interest to young people who are currently studying in secondary schools, and the teachers' curiosity in answering these questions is important. In the course of the study, carried out in the regional and district archives, the information related to the labor activity of those who returned from the war with disabilities was studied. In 1971, 49 of the invalids of the Great Patriotic War became blind.[2] Togaev Normurod, Hasanov Eshbori from Sariosi region, Pardaev Toshtemir, Rakhimov Turdi, Jabborov Khamro, Normurodov Jabbor from Shurchinsky region, Ayupov Khasan, Bikbaev Gumar, Normurodov O., Boimurodov Rajab from Termez, Yudamatku A. Jalilov Chori from Sherabad region, Nazarov Mamat, Yuldashev R., Mamatkulov A. from Baysun region, Kholmurodov X [3]. Abdukarimov B. from Kumkurgan region [4] and others were engaged in labor activities even after returning from the war. In particular, Hasanov E. [5] They were engaged in sewing, Khudoinazarov P., Davlatov D., Ishbaev X, Valiev I. [6] Coverage of these topics, the reader will undoubtedly have to imagine that period of history, feel the spirit of this period and to some extent present oneself as an official of this period.As President Sh.M. Mirzaev noted, "I would like to say about the attitude towards war veterans, our respected veterans, who today are alive in our ranks and benefit our lives. It will not be a mistake to say that their lives are precious, to take care of them while they are alive, to lighten their burden, to value and respect them, and this is both a duty and a duty for all of us, especially for the leaders of the government. " [7] 3769 soldiers from Surkhandarya were awarded orders and medals of the country, 6 heroes from Surkhandarya became heroes of the Soviet Union, and 3 heroes from Surkhandarya were awarded the Order of Glory. Kholiyorov Bobogul, Pardaev Toshtemir, Boimurodov Rajab, Shaimardonov Haydar, Hasanov Eshbori, Noboev Murod, who returned 
CURRENT RESEARCH JOURNAL OF PEDAGOGICS 2(6): 157-160, June

2021 DOI: https://doi.org/10.37547/pedagogics-crjp-02-06-29

ISSN 2767-3278

(C)2021 Master Journals

\section{Crossref dof 81 Google}

Accepted 25th June, 2021 \& Published 30 $0^{\text {th }}$ June, 2021

from the war with disabilities, were also awarded many orders and medals [8].

Results and discussion.Working with the map also helps to awaken the creative spirit in history lessons. To do this, working with a map teaches students to follow the course of events using a map, instilling in students a sense of curiosity about historical events. Below are examples of assignments for organizing creative work using a map.

1. Development of a map of cities-museums during the Second World War.

2. Making a map based on the stories of participants of the Second World War in Surkhandarya.

At the same time, the student draws a map of cities liberated from fascism, interviewing war veterans or their children living in their area. What will be the main role of the teacher in this process? First of all, when students are working on a map on their own, special attention should be paid to its portrayal using various pictures, illustrations and comments. Second, when mapping, students should be reminded of the geographic requirements for mapping and, if necessary, explain them. In this process, students can develop independent thinking and independent thinking through the efficient use of resources from research.

\section{Conclusion}

A history teacher should always remember one rule. According to the interpretation of this rule, historical science, first of all, teaches every citizen, especially our youth, to understand the meaning and essence of the people's past, to appreciate our rich spiritual and cultural heritage, to protect it as the world. the apple of my eye, and finally be proud of them. In conclusion:

1) Today, various methods and means of teaching are scientifically substantiated in the methodology of teaching science. Depending on the content and nature of the didactic material chosen by the teacher, the student will be able to apply it in the educational process using appropriate methods and tools.it will be easier to solve the problem of increasing activity;

2) In the process of drawing up a lesson plan, it is relatively easy for a teacher to take into account the cognitive abilities of students, the formation of their historical knowledge.

\section{REFERENCES}

1. Mirziyoev Sh. We will resolutely continue our path of national development and raise it to a new level. T., "Uzbekistan", NIMU, 2018. - 592 pages.

2. Borzova L. Igry na uroke istorii. - M .: "Vlados-Press", 2003.

3. Surkhandarya region state archive 553 fund, 1 - list, 6 - work, 1 - sheet

4. State archive of Surkhandarya region 553 fund, 1 - list, 6 - work, 2-3 - sheets

5. State archive of Surkhandarya region 553 fund, 1 - list, 64 - work, 18 - sheet

6. Surkhandarya region state archive 553 fund, 1 - list, 6 - work, 2 - sheet

7. State archive of Surkhandarya region 553 fund, 1 - list, 6 - work, 40 - sheets

8. State archive of Surkhandarya region 553 fund, 1 - list, 7 - work, 8 - sheets

9. Yuldashev J., Usmonov S.A. Introduction of modern pedagogical technologies. - T., 2008.

10. Toshpulatov T., Gafforov Ya. Methods of teaching history. - T., "University”, 1999. 
CURRENT RESEARCH JOURNAL OF PEDAGOGICS 2(6): 157-160, June

2021 DOI: https://doi.org/10.37547/pedagogics-crjp-02-06-29

ISSN 2767-3278

(C)2021 Master Journals

Crossief do) 801 Google

Accepted 25th June, 2021 \& Published 30 $0^{\text {th }}$ June, 2021

11. Newspaper "For advanced Surkhan", July 3, 1941, August 5, October 9, 1941.

12. "Leninskaya znamya" newspaper. October 5 , 1943. № 194

13. Tursunov S. et al. Memory is eternal, dignity is eternal. T. "Fan" publishing house, 2010 B. 10-11.

14. Memory. Surkhandarya region. Volumes 1 and 2. - T .: Abdulla Qodiri National Heritage Publishing House, 1996.

15. Khalimovich, O. N., Rasuljanovna, I. N., \& Shakarovich, G. I. (2020). The Purpose and Outcome of Diplomatic Missions in the II-I Centuries Between Central Asia And China. Journal of Critical Reviews, 7(9), 126-128. 